\title{
Exposure to infection with Hantavirus (serotype Dobrava/Hantaan) among forestry workers in Poland
}

\author{
Paula Wróblewska-Łuczka ${ }^{1} \bowtie$, Jolanta Chmielewska-Badora ${ }^{1}$, Jacek Zwoliński ${ }^{1}$, \\ Elżbieta Monika Galińska ${ }^{1}$, Piotr Adamczuk ${ }^{1}$, Wioletta Żukiewicz-Sobczak ${ }^{2}$, \\ Jerzy Zagórski ${ }^{2}$, Krzysztof Tomasiewicz ${ }^{3}$, Andrzej Wojtyła ${ }^{4}$ \\ ${ }^{1}$ Institute of Rural Health, Jaczewskiego 2, 20-090 Lublin, Poland, phone: +48 817184488 , \\ e-mail: wroblewska.paula88@gmail.com \\ ${ }^{2}$ Pope John Paul II State School of Higher Education in Biala Podlaska, Sidorska 95/97, 21-500 Biała Podlaska, Poland \\ ${ }^{3}$ Medical University of Lublin, Department of Infectious Diseases, Staszica 16, 20-081 Lublin, Poland \\ ${ }^{4}$ Higher Vocational State School in Kalisz, Department of Medicine, Nowy Świat 4, 62-800 Kalisz, Poland
}

\section{Abstract}

The hosts of Hantavirus are rodents, while they are transmitted to humans via aerosol, or by direct contact with them. The primary goal of the study was evaluation of the state of health of forestry workers by laboratory diagnosis of the diseases caused by Hantavirus Dobrava/Hantaan. The study covered a group of 820 randomly selected employees of the State Forests from 32 Forest Districts located in the area of the whole of Poland. The results of the study show that the largest number of positive results were registered in the Augustów Forest District - 3 cases (10\%), and in Piotrków Trybunalski - 3 cases (11.5\%). For the whole of Poland, 25 seropositive results were noted (3\%) and 76 results were doubtful (9.3\%). The results of the conducted study suggest the occurrence of Hantavirus Dobrava in large forest complexes on the territory of Poland. People residing and working in these areas are exposed to infection, and this exposure seems to be comparable with data from other countries.

\section{KeY WORDS}

Hantavirus, forestry workers, rodents, occupational exposure

\section{INTRODUCTION}

Hantavirus is one of the types of RNA viruses belonging to the family Bunyaviridae (approximately 300 viruses infecting humans, animals, arthropods, and plants) (Schmaljohn et al. 2001). The hosts of hantaviruses are rodents, while they are transmitted to humans via aerosol containing excrements or secretions from infected rodents, or by direct contact with them. The time for which hantaviruses remain in excrements or secretions of rodents varies according to the type of rodent, and the type of material dealt with: saliva, urine, or stool. In the case of mice of the genus Apodemus, hantaviruses are present for the longest 
time in mouse urine (Lee et al. 1981). Hantaviruses are divided into the Old World and the New World viruses, according to the type of rodent which transmits them, and the geographical area in which they occur (Schmaljohn 1996). Sorotype Dobrava is transmitted by the yellow-necked field mouse Apodemus flavicollis, which in Europe is responsible for the more serious cases of HFRS (haemorrhagic fever with renal syndrome) (Heyman et al. 2009).

Mice of the genus Apodemus, including the genus A. flavicollis, occur in majority of European countries. A. flavicollis transmits hantavirus serotype Dobrava, which is responsible for severe cases of HFRS, with a high death rate in Europe (Xiao et al. 1993). The virus of serotype Dobrava is genetically related with the virus Saaremaa isolated from mice Apodemus agrarius, which also occurs in Europe (Nemirov et al. 1999). The mice Apodemus agrarius is also present in Asia, where it is responsible for the transmission of hantavirus serotype Hantaan, genetically closely related with the virus Dobrava (Baek et al. 2006). To-date, it has been found that Apodemus flavicollis, A. agrarius, and $A$. ponticus are responsible for the transmission of Dobrava and Dobrava-like viruses in Europe (Jakab et al. 2007). Infections with Dobrava virus (from A. flavicollis) have been identified to-date only in the region of the Balkans (Papa et al. 1998; Avsic-Zupanc et al. 1999), although this mouse is also prevalent in other areas. The Dobrava-like viruses transmitted by $A$. agrarius have been detected in Central and Eastern Europe (Estonia, Russia, Denmark, Slovenia, and Slovakia) (Jakab et al. 2007; Klein and Calisher 2007).

The period of incubation of HFRS is approximately 3 weeks (Kramski et al. 2009). The first symptoms of HFRS are primarily high fever lasting for the first several days, as well as headaches, thrombocytopenia, flu-like symptoms, abdominal pain, nausea, and vomiting; 4-10 days after that, the renal symptoms occur - oliguria, followed by polyuria (Heyman et al. 2009). Typically, HFRS includes five phases of the disease: fever, hypotensia, oliguria, polyuria, and convalescence. Approximately $40 \%$ of patients infected with the virus Hantaan require dialyses. Death is most frequently the result of complications related with renal failure or haemorrhage. The intensification of symptoms is related with the serotype of the hantavirus that caused the disease; however, it also depends on individual predispositions of the human body. Mortality in Europe for infection with the serotype Dobrava is from 9-12\% (Papa et al. 1998). Usually, the risk of contracting HFRS is related with work in forestry, agriculture, construction works in the vicinity of forests, or in or near habitats of rodents. The risk of infection is also associated with the work of a zoologist or a veterinarian who deals with rodents (Vapalahti et al. 2010).

\section{Objective}

The primary goal of the study was laboratory diagnosis of the diseases caused by Hantavirus serotype Dobrava/Hantaan of forestry workers.

\section{Material AND Methods}

The study covered a group of 820 randomly selected employees of the State Forests from 32 Forest Districts located in the area of whole of Poland. The study group included 678 males (82.7\%) and 142 females (17.3\%); mean age $47 \pm 8$.

Prior to the study, each person was precisely informed concerning its goal and course, and the possibility to withdraw from the participation in the study at each stage, without incurring any consequences. From all forestry workers, blood was collected, centrifuged on the spot, and sera preserved for further studies. In addition, the medical history was taken concerning the exposure to contact with rodents, number of hours of work in the forest, and presently reported complaints. The study was approved by the Bioethics Commission at the Institute of Rural Health (approval number $8 / 2012$, date 28.02.2012).

In all 820 study participants, serologic tests were performed for hantavirus Dobrava/Hantaan IgM and $\mathrm{IgG}$, by immunoenzymatic test (ELISA), PROGEN Biotechnik GmbH, Germany. The tests and the determined positive and doubtful results were performed in accordance with the research procedure included by the manufacturer. Statistical analyses were performed using chi $^{2}$ test. 


\section{RESULTS}

Antibodies (IgM and IgG class) against the hantaviruses were examined using antigens of the strain Dobrava/ Hantaan. Table 1 presents results obtained in individual Forest Districts.

The results of the presented study show the largest number of seropositive results among forestry workers that were found in the Regions of Katowice (6\%), Łódź (5.9\%), Białystok (5.5\%), Warsaw (4.3\%), and Kielce (4.1\%). The largest number of positive results were registered in the Augustów Forest District - 3 cases (10\%), and in Piotrków Trybunalski Forest District -3 cases (11.5\%). No positive results were observed in the regions of Bydgoszcz, Zielona Góra, Kraków, and Lublin. For the whole of Poland, 25 seropositive results were noted (3\%) and 76 results were doubtful $(9.3 \%)$. Figure 1 presents the distribution of positive and doubtful results in the area of Poland.

Figure 1 shows that both positive and doubtful results occur in the area of the whole of Poland. The largest number of positive results are observed in the central and southern Poland. In the north of the country, positive and doubtful results were noted in Forest Districts located on the edge of Poland: in Augustów Forest District - 3 positive (10\%), 9 doubtful (30\%), in Międzyzdroje Forest
District -2 positive (8\%), 5 doubtful $(20 \%)$. No positive or doubtful results were found in the Góra Śląska Forest District in the Wrocław Region, and the Namysłów Forest District in the Opole Region. The results obtained may suggest a high prevalence of mice of the species $\mathrm{Ap}$ odemus, which is the vector of hantavirus Dobrava.

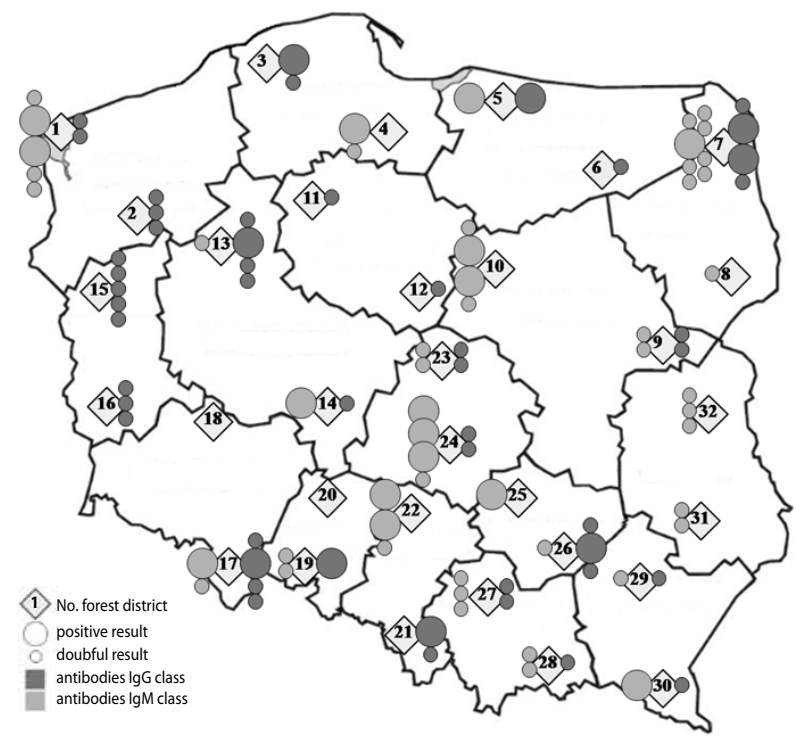

Figure 1. Distribution of positive and doubtful results in the area of Poland, according to individual administrative regions and Forest Districts

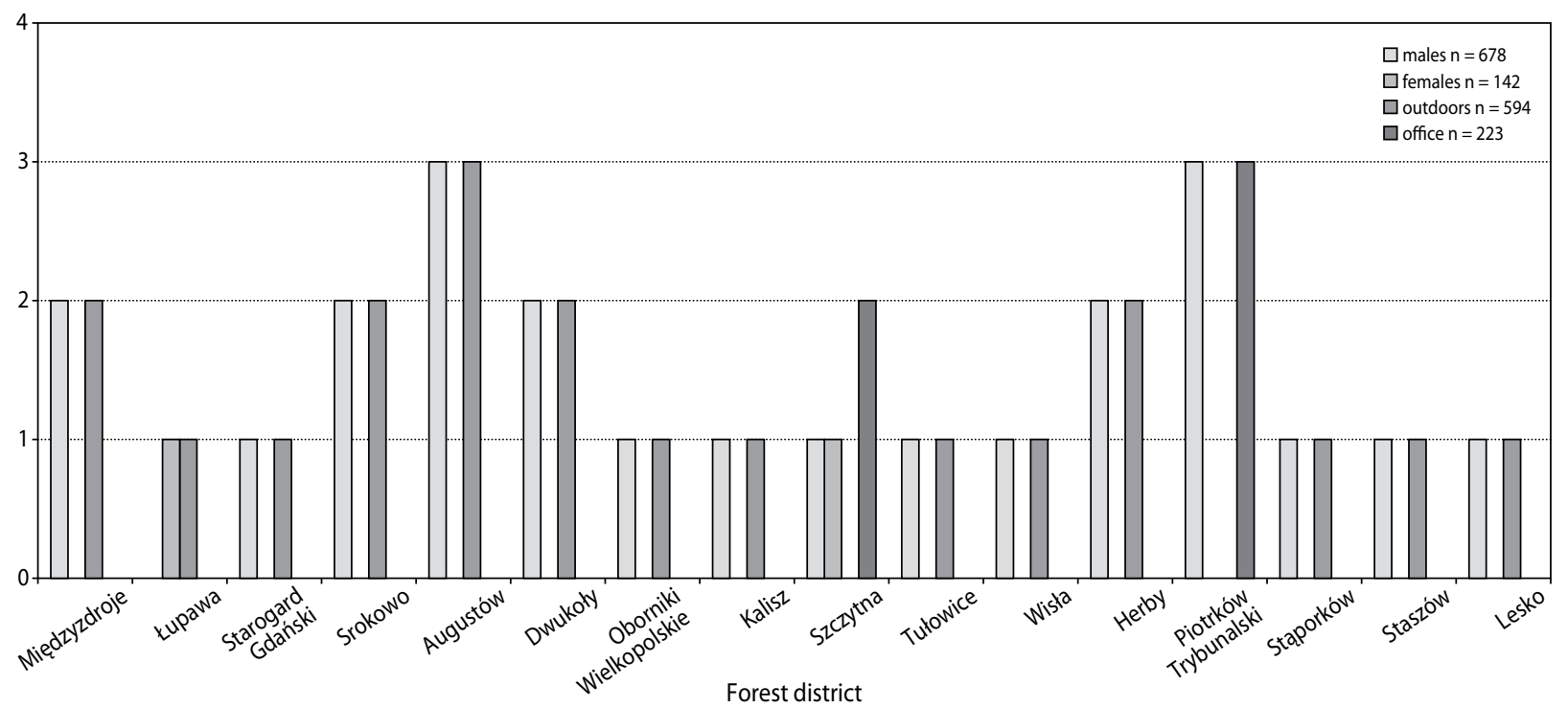

Figure 2. Distribution of seropositive results according to gender and type of work performed in the Forest District (outdoors $-50 \%$ and more of working time outdoors; office - less than $50 \%$ of working time outdoors; lack of data concerning working time for three employees) 
Table 1. Results of studies for the presence of antibodies IgM and IgG class against hantaviruses Dobrava/Hantaan, according to individual administrative regions and Forest Districts

\begin{tabular}{|c|c|c|c|c|c|c|c|c|}
\hline \multirow{2}{*}{ Region } & \multirow{2}{*}{ No. } & \multirow{2}{*}{ Forest District } & \multirow{2}{*}{$\begin{array}{c}\text { No. of } \\
\text { employees } \\
\text { examined }\end{array}$} & \multicolumn{2}{|c|}{ No. of doubtful results } & \multicolumn{2}{|c|}{ No. of positive results } & \multirow{2}{*}{$\begin{array}{c}\% \text { of positive } \\
\text { results for } \\
\text { individual regions }\end{array}$} \\
\hline & & & & $\operatorname{IgM}$ & $\operatorname{IgG}$ & $\operatorname{IgM}$ & $\operatorname{IgG}$ & \\
\hline \multirow{2}{*}{ Szczecin } & 1 & Międzyzdroje & 25 & 3 & 2 & 2 & 0 & \multirow{2}{*}{$4 \%$} \\
\hline & 2 & Drawsko Pomorskie & 25 & 0 & 3 & 0 & 0 & \\
\hline \multirow{2}{*}{ Gdańsk } & 3 & Łupawa & 25 & 0 & 1 & 0 & 1 & \multirow{2}{*}{$4 \%$} \\
\hline & 4 & Starogard Gdański & 25 & 1 & 0 & 1 & 0 & \\
\hline \multirow{2}{*}{ Olsztyn } & 5 & Srokowo & 26 & 0 & 0 & 1 & 1 & \multirow{2}{*}{$3.8 \%$} \\
\hline & 6 & Szczytno & 26 & 0 & 1 & 0 & 0 & \\
\hline \multirow{2}{*}{ Białystok } & 7 & Augustów & 30 & 7 & 2 & 1 & 2 & \multirow{2}{*}{$5.5 \%$} \\
\hline & 8 & Bielsk Podlaski & 25 & 1 & 0 & 0 & 0 & \\
\hline \multirow{2}{*}{ Warsaw } & 9 & Sarnaki & 22 & 2 & 2 & 0 & 0 & \multirow{2}{*}{$4.3 \%$} \\
\hline & 10 & Dwukoły & 25 & 2 & 0 & 2 & 0 & \\
\hline \multirow{2}{*}{ Bydgoszcz } & 11 & Woziwoda & 25 & 0 & 1 & 0 & 0 & \multirow{2}{*}{0} \\
\hline & 12 & Włocławek & 26 & 0 & 1 & 0 & 0 & \\
\hline \multirow{2}{*}{ Poznań } & 13 & Oborniki Wielkopolskie & 25 & 1 & 3 & 0 & 1 & \multirow{2}{*}{$4 \%$} \\
\hline & 14 & Kalisz & 25 & 0 & 1 & 1 & 0 & \\
\hline \multirow{2}{*}{$\begin{array}{l}\text { Zielona } \\
\text { Góra }\end{array}$} & 15 & Kłodowa k. Gorzowa & 25 & 0 & 5 & 0 & 0 & \multirow{2}{*}{0} \\
\hline & 16 & Wymiarki & 25 & 0 & 3 & 0 & 0 & \\
\hline \multirow{2}{*}{ Wrocław } & 17 & Szczytna & 25 & 1 & 3 & 1 & 1 & \multirow{2}{*}{$3.9 \%$} \\
\hline & 18 & Góra Śląska & 26 & 0 & 0 & 0 & 0 & \\
\hline \multirow{2}{*}{ Opole } & 19 & Tułowice & 25 & 2 & 0 & 0 & 1 & \multirow{2}{*}{$2 \%$} \\
\hline & 20 & Namysłów & 25 & 0 & 0 & 0 & 0 & \\
\hline Katowice & 21 & Wisła & 25 & 0 & 1 & 0 & 1 & 60 \\
\hline Katowice & 22 & Herby & 25 & 1 & 0 & 2 & 0 & $6 \%$ \\
\hline Jódź & 23 & Grotniki & 25 & 2 & 2 & 0 & 0 & $50 \%$ \\
\hline LOUZ & 24 & Piotrków Trybunalski & 26 & 1 & 2 & 3 & 0 & 5.970 \\
\hline Kielce & 25 & Stąporków & 24 & 0 & 0 & 1 & 0 & $41 \%$ \\
\hline Kielce & 26 & Staszów & 25 & 1 & 2 & 0 & 1 & $4.1 \%$ \\
\hline$Y$ mol- & 27 & Olkusz & 32 & 3 & 2 & 0 & 0 & 0 \\
\hline Krakow & 28 & Stary Sącz & 25 & 2 & 1 & 0 & 0 & 0 \\
\hline Rzeszów & 29 & Nowa Dęba & 25 & 1 & 1 & 0 & 0 & $20 \%$ \\
\hline KZESZOW & 30 & Lesko & 25 & 0 & 1 & 1 & 0 & $2 \%$ \\
\hline I ublin & 31 & Janów Lubelski & 31 & 2 & 0 & 0 & 0 & 0 \\
\hline Luonm & 32 & Radzyń Podlaski & 26 & 3 & 0 & 0 & 0 & 0 \\
\hline & & TOTAL & 820 & $36(4.4 \%)$ & $40(4.9 \%)$ & $16(2 \%)$ & $9(1.1 \%)$ & $25(3 \%)$ \\
\hline
\end{tabular}

Figure 2 demonstrates the distribution of seropositive results according to gender and type of work performed.
Positive results were observed in $23(3.4 \%)$ males and $2(1.4 \%)$ females (Fig. 2). It was confirmed that gender has no effect on the frequency of 
occurrence of infection with hantavirus Dobraval Hantaan. These results are statistically insignificant $\left(\mathrm{chi}^{2}=1.5633 ; \mathrm{p}=0.211176\right)$. Also, no statistical significance $\left(\mathrm{chi}^{2}=0.6916 ; \mathrm{p}=0.40563\right)$ was noted for infection with hantavirus Dobrava/Hantaan with respect to the working time outdoors. In persons employed outdoors, $20(3.4 \%)$ positive results were found; while among office workers, $5(2.2 \%)$ positive results were found. Positive results in office workers were also noted in the Piotrków Trybunalski and Szczytna Forest Districts. Positive results among office workers may suggest that these Forest Districts are located in areas which are the habitats of mice of the species Apodemus, or the presence of excretions of these rodents in office rooms (due to insufficient protection against rodents).

\section{DISCUSSION}

Dissemination of hantaviruses depends on the migration of infected rodents in individual areas, their interaction with the environment, as well as changes of climate or growth of the population of rodents. HFRS epidemics correlate with an increasing population of rodents in individual regions. An increase in the population of rodents is noted in the countries of Central Europe, the Balkans or Scandinavia, and are probably caused by accumulation of forest tree fruits on the ground, which are abundant food for forest rodents. This is also due to the warming of climate improving the blooming of trees, or the production of seeds (Schwarz et al. 2009; Tersago et al. 2009). Other studies showed that in China a good yield of seeds, low rainfall or lack of floods, also results in the growth of mice population, and consequently, more frequent cases of HFRS transmitted by Apodemus agrarius (Hu et al. 2007).

Apart from climate, the probability of transmission of hantaviruses to humans is also influenced by the type of work performed. Hantaviruses are transmitted with aerosol contaminated with excrements and secretions. The infection often occurs among forestry workers and farmers, as well as among construction workers and other employees, who - during work - stay in unused buildings (e.g., barns) to which the rodents have had an access, and which are being cleaned up for subsequent use (Van Loock et al. 1999).
In the Balkans, an increasing number of infections with hantavirus Dobrava is observed in 'fattening years', that is, in the years when there is a growth of the population of rodents resulting from climatic changes and an increased accessibility of food. Considerable increases in the occurrence of hantaviruses have been described for countries such as Bosnia and Herzegovina (increase by $5 \%$ ), Greece (by $4 \%$ ), and Slovenia (by 1.7\%) (Heyman et al. 2009). In 2007, in France, Austria, and Germany, 3 to 5 times more cases of infection were noted, whereas in Sweden, even 10 times more as compared to the average value concerning the former decade (Heyman et al. 2011).

Investigations were also conducted that focused on the exposure of forestry workers to infections with hantaviruses resulting from the character of their work. German researchers examined for hantaviruses (serotype Dobrava/ Tula) a population of 563 forestry workers from the southern regions of Germany. Serologic tests showed $9.1 \%$ of positive results (Mertens et al. 2011). Another study concerned a group of 722 forestry workers from Germany, from the region of North Rhine-Westphalia, in whom $6 \%$ of positive results were confirmed (for serotype Puumala) (Jurke et al. 2015). However, in the south-western regions of the United States, no antibodies against hantaviruses were found among a group of 140 forestry workers exposed to contact with rodents (Vitek et al. 1996). Among forestry workers in Hungary, $4.6 \%$ of seropositve results were confirmed in the study group of 835 workers (for mix of serotypes Puumala and Dobrava) (Oldal et al. 2014). In Switzerland, studies were carried out concerning the exposure to infection with hantaviruses among a group of 1,693 farmers, forestry workers and soldiers. Low percentages of positive results were observed on the level up to $1.9 \%$, according to the group examined (Schultze et al. 2007). In Holland, a comprehensive study was carried out seeking antibodies against hantaviruses among more than 10,000 serum samples from humans and animals. Positive results were confirmed in approximately $10 \%$ of patients with the symptoms of nephropathy, as well as in groups at occupational risk - in $6 \%$ animal trappers, $4 \%$ forestry workers, $2 \%$ laboratory staff, and in $0.4 \%$ of farmers (Groen et al. 1995). Also, the frequency of occurrence of antibodies against hantaviruses was determined in Slovakia for a group of 2,133 people examined. In the western part of Slovakia, the percentage of positive results was lower 
$(0.54 \%)$ as compared to the eastern part of the country (1.91\%). The largest number of seropositive results was noted in a group of forestry workers in eastern Slovakia (5.88\%) (Sibold et al. 1999). The percentage results of the presented study seem to be comparable to the results of studies conducted in other countries. This study showed $3 \%$ of positive results for antibodies against hantaviruses Dobrava/ Hantaan among forestry workers in the whole Poland.

The first case of HFRS in Poland was noted in the area of the Rzeszów Region in 2007 (Nowakowska et al. 2007). Many studies indicate the occurrence of zoonoses in Poland, which are related with exposure to contact with wild animals. These diseases constitute a serious epidemiological problem; especially in the environment of work of forestry workers, they have the character of occupational diseases (Dutkiewicz et al. 2011). Since 2007 , the diseases caused by hantaviruses have been reported to the National Institute of Public Health. These reports come mainly from the Rzeszów Region, which evidences that this is an endemic region for the occurrence of hantaviruses. Epidemiological reports concerning the years 2007-2015, issued by the National Institute of Public Health, indicate that there are approximately 6-8 cases annually, on an average, the incidence of this disease being 0.02 per 100,000 population. In 2014, an increase in the number of cases was noted - 54 cases of diseases caused by hantaviruses, including 53 cases found in the Rzeszów Region. Nearly $100 \%$ of all the reported cases were hospitalized (National Institute of Public Health, 2007-2015). The presented study showed one positive result and 3 doubtful results for the Forest Districts in the Rzeszów Region. The frequency of positive results among forestry workers in this region is $2 \%$.

Polish researchers also carried out studies concerning the occurrence of infections with hantaviruses among forestry workers. Some of the studies concerned only infection with the hantavirus serotype Puumala, during which no positive results were observed among 86 forestry workers from the Upper Silesian Region, whereas positive results were noted among zoologists (Sadkowska-Todys et al. 2007; Gut et al. 2007a). The presented study showed 3 positive results $(6 \%)$ among forestry workers from Forest Districts in the Katowice Region. According to the studies by Gut W. et al. among the examined group of Polish zoologists $(n=78), 7$ doubtful results were found (9\%) for the serotype Hantaan, which is closely related with the serotype Dobrava. Additionally, doubtful results correlated with doubtful and positive results for the serotype Puumala (Gut et al. 2007b). Studies carried out among forestry workers $(n=216)$ from the areas of southern and eastern Poland revealed 6 positive results $(2.8 \%)$ and 26 doubtful results (12\%) for antibodies against hantaviruses Dobrava/Hantaan. Forestry workers with positive results were employees who spent more than $50 \%$ of their working time in the forest (ŻukiewiczSobczak et al. 2014). Also, another report concerned the exposure of forestry workers to infection with hantaviruses. The study included 161 employees of Forest Districts from the areas of south-eastern Poland (Forestry Districts of Zwierzyniec, Puławy, Biała Podlaska, and Roztocze National Park). The presence of anti-hantavirus antibodies IgG was found in only 4 persons examined (2.5\%), and 2 infections (1.2\%) were caused by the serotype Dobrava. No specific antibodies were observed in the IgM class (Knap et al. 2010). The presented study also confirmed a low percentage of infections with the serotype Dobrava in the areas of south-eastern Poland: 0\% of positive results in Lublin Region, $2 \%$ in Rzeszów Region, and $4.1 \%$ in Kielce Region. Other studies conducted among forestry workers $(n=69)$ in north-eastern Poland (Regions of Białystok and Olsztyn) revealed 2 positive results $(2.9 \%)$ for the presence of antibodies against hantaviruses Hantaan (Grygorczuk et al. 2008). The current study confirmed a larger number of positive results for the serotype Dobrava/Hantaan in these regions: 2 positive results $(3.8 \%)$ in the Olsztyn Region and 3 positive results (5.5\%) in the Białystok Region. Antibodies reacting with antigens Hantaan give strong cross-reactions (due to the genetic relationship) with serotypes Dobrava in the Balkans and Saaremaa in Central Europe (Baek et al. 2006). Many data concerning the results of serologic tests suggest the occurrence of probably asymptomatic or poorly symptomatic, and consequently, undiagnosed infections with hantaviruses in humans on the territory of Poland (Sadkowska-Todys et al. 2007; Grygorczuk et al. 2008).

\section{CONCLUSIONS}

The results of the conducted study suggest the occurrence of hantaviruses serotype Dobrava in large forest complexes on the territory of Poland. People residing 
and working in these areas are exposed to infection. The majority of infections probably have an asymptomatic course. It seems important to draw attention to preventive actions among forest workers, especially the use of personal protection equipment.

\section{ACKNOWLEDGEMENTS}

The research material underlying the presented publication was collected within a research project No OR2717-39/11, funded by the General Directorate of The State Forests entitled 'Selected health risks in the employees of State Forests work environment in Poland with special emphasis on occupational diseases'.

\section{DECLARATION OF INTEREST}

None

\section{REFERENCES}

Avsic-Zupanc T., Petrovec M., Furlan P., Kaps R., Elgh F., Lundkvist A. 1999. Hemorrhagic fever with renal syndrome in the Dolenjska region of Slovenia - a 10-year survey. Clinical Infectious Diseases, 28, 860-865.

Baek L.J., Kariwa H., Lokugamage K., Yoshimatsu K., Arikawa J., Takashima I., Kang J.I., Moon S.S., Chung S.Y., Kim E.J., Kang H.J., Song K.J., Klein T.A., Yanagihara R., Song J.W. 2006. Soochong virus: an antigenically and genetically distinct hantavirus isolated from Apodemus peninsulae in Korea. Journal of Medical Virology, 78, 290-297.

Dutkiewicz J., Cisak E., Sroka J., Wójcik-Fatla A., Zając V. 2011. Biological agents as occupational hazards - selected issues. Annals of Agricultural and Environmental Medicine, 18 (2), 286-293.

Groen J., Gerding M.N., Jordans J.G., Clement J.P., Nieuwenhuijs J.H., Osterhaus A.D. 1995. Hantavirus infections in The Netherlands: epidemiology and disease. Epidemiology and Infection, 114 (2), 373-383.

Grygorczuk S., Pancewicz S., Zajkowska J., Kondrusik M., Świerzbińska R., Moniuszko A., Paw-
lak-Zalewska W. 2008. Detection of anti-hantavirus antibodies in forest workers in the north-east of Poland. Przeglad Epidemiologiczny, 62 (3), 531-537.

Gut W., Siennicka J., Sadkowska-Todys M., Baumann A., Litwińska B. 2007a. Hantavirus specific $\mathrm{IgG}$ antibodies in population of zoologists and forest workers. Przeglad Epidemiologiczny, 61 (3), 483-488.

Gut W., Siennicka J., Sadkowska-Todys M., Gozdowska J., Litwińska B. 2007b. The cross and unspecific reactions in serological examination for antibodies against of hantavirus Puumala. Przeglad Epidemiologiczny, 61 (3), 489-495.

Heyman P., Ceianu C.S., Christova I., Tordo N., Beersma M., João Alves M., Lundkvist A., Hukic M., Papa A., Tenorio A., Zelená H., Eßbauer S., Visontai I., Golovljova I., Connell J., Nicoletti L., Van Esbroeck M., Gjeruldsen Dudman S., Aberle S.W., Avšić-Županc T., Korukluoglu G., Nowakowska A., Klempa B., Ulrich R.G., Bino S., Engler O., Opp M., Vaheri A. 2011. A five-year perspective on the situation of haemorrhagic fever with renal syndrome and status of the hantavirus reservoirs in Europe, 2005-2010. Euro Surveillance, 16 (36), 19961

Heyman P., Vaheri A., Lundkvist A., Avsic-Zupanc T. 2009. Hantavirus infections in Europe: from virus carriers to a major public health problem. Expert Review of Anti-infective Therapy, 7 (2), 205-217.

Hu W., Mengersen K., Bi P., Tong S. 2007. Time-series analysis of the risk factors for haemorrhagic fever with renal syndrome: comparison of statistical models. Epidemiology and Infection, 135 (2), 245-252.

Jakab F., Horvath G., Ferenczi E., Sebok J., Varecza Z., Szucs G. 2007. Detection of Dobrava hantaviruses in Apodemus agrarius mice in the Transdanubian region of Hungary. Virus Research, 128, 149-152.

Jurke A., Bannert N., Brehm K., Fingerle V., Kempf V.A., Kömpf D., Lunemann M., Mayer-Scholl A., Niedrig M., Nöckler K., Scholz H., Splettstoesser W., Tappe D., Fischer Silke F. 2015. Serological survey of Bartonella spp. Borrelia burgdorferi, Brucella spp., Coxiella burnetii, Francisella tularensis, Leptospira spp., Echinococcus, Hanta-. TBE- and XMR-virus infection in employees of two forestry enterprises in North Rhine-Westphalia, Germany, 2011-2013. International Journal of Medical Microbiology, 305 (7), 652-662. 
Klein S.L., Calisher C.H. 2007. Emergence and persistence of hantaviruses. Current Topics in Microbiology and Immunology, 315, 217-252.

Knap J.P., Nowakowska A., Dutkiewicz J., Zając V., Wójcik-Fatla A., Chmielewska-Badora J., Strupieniuk Z. 2010. Detection of antibodies against hantaviruses in forestry workers of the Roztocze National Park and Puławy Forest Inspectorate (Lublin Macroregion). Preliminary report. Medycyna Ogólna i Nauki o Zdrowiu, 16 (2), 201-216.

Kramski M., Machazi K., Klempa B., Krüger D.H. 2009. Nephropathia epidemica with a 6-week incubation period after occupational exposure to Puumala hantavirus. Journal of Clinical Virology, 44, 99-101.

Lee P.W., Amyx H.L., Gibbs C.J. Jr, Gajdusek D.C., Lee H.W. 1981. Propagation of Korean hemorrhagic fever virus in laboratory rats. Infection and Immunity, 31, 334-338.

Mertens M., Hofmann J., Petraityte-Burneikiene R., Ziller M., Sasnauskas K., Friedrich R., Niederstrasser O., Krüger D.H., Groschup M.H., Petri E., Werdermann S., Ulrich R.G. 2011. Seroprevalence study in forestry workers of a non-endemic region in eastern Germany reveals infections by Tula and Dobrava-Belgrade hantaviruses. Medical Microbiology and Immunology, 200 (4), 263-268.

National Institute of Public Health - National Institute of Hygiene - Department of Epidemiology. Infectious diseases and poisonings in Poland in 2007-2015.

Nemirov K., Vapalahti O., Lundkvist A., Vasilenko V., Golovljova I., Plyusnina A., Niemimaa J., Laakkonen J., Henttonen H., Vaheri A., Plyusnin A. 1999. Isolation and characterization of Dobrava hantavirus carried by the striped field mouse ( $A p$ odemus agrarius) in Estonia. Journal of General Virology, 80, 371-379.

Nowakowska A., Heyman P., Knap J.P., Burzyński W., Witas M. 2009. The first established focus of hantavirus infection in Poland, 2007. Annals of Agricultural and Environmental Medicine, 16 (1), 79-85.

Oldal M., Németh V., Madai M., Pintér R., Kemenesi G., Dallos B., Kutas A., Sebők J., Horváth G., Bányai K., Jakab F. 2014. Serosurvey of pathogenic hantaviruses among forestry workers in Hungary.
International Journal of Occupational Medicine and Environmental Health, 27 (5), 766-773.

Papa A., Johnson A.M., Stockton P.C., Bowen M.D., Spiropoulou C.F., Alexiou-Daniel S., Ksiazek T.G., Nichol S.T., Antoniadis A. 1998. Retrospective serological and genetic study of the distribution of hantaviruses in Greece. Journal of Medical Virology, 55 (4), 321-327.

Sadkowska-Todys M., Gut W., Baumann A., Siennicka J., Litwińska B., Zieliński A. 2007. Occurrence of human hantavirus infections in Poland. Przeglad Epidemiologiczny, 61(3), 497-503.

Schmaljohn C. 1996. Molecular biology of hantaviruses. In: The Bunyaviridae (ed.: R.M. Elliot). Plenum Press, New York, 63-90.

Schmaljohn C.S., Hooper J.W. 2001. Bunyaviridae: the viruses and their replication. In: Fields virology, vol. 2, 4th ed. (eds.: D.M. Knipe, P.M. Howley, D.E. Griffin, R.A. Lamb, et al.). Lippincott Williams \& Wilkins, Philadelphia, 1581-1602.

Schultze D., Fierz W., Matter H.C., Bankoul S., Niedrig M., Schmiedl A. 2007. Cross-sectional survey on hantavirus seroprevalence in Canton St. Gallen, Switzerland. Swiss Medical Weekly, 137 (1/2), 21-26.

Schwarz A.C., Ranft U., Piechotowski I., Childs J.E., Brockmann S.O. 2009. Risk factors for human infection with Puumala virus, southwestern Germany. Emerging Infectious Diseases, 15, 1032-1039.

Sibold C., Meisel H., Lundkvist A., Schulz A., Cifire F., Ulrich R., Kozuch O., Labuda M., Krüger D.H. 1999. Short report: simultaneous occurrence of Dobrava, Puumala and Tula Hantaviruses in Slovakia. The American Journal of Tropical Medicine and Hygiene, 61 (3), 409-411.

Tersago K., Verhagen R., Servais A., Heyman P., Ducoffre G., Leirs H. 2009. Hantavirus disease (nephropathia epidemica) in Belgium: effects of tree seed production and climate. Epidemiology and Infection, 137, 250-256.

Van Loock F., Thomas I., Clement J., Ghoos S., Colson P. 1999. A case-control study after a hantavirus infection outbreak in the south of Belgium: who is at risk? Clinical Infectious Diseases, 28 (4), 834-839.

Vapalahti K., Virtala A.M., Vaheri A., Vapalahti O. 2010. Case- control study of Puumala virus infec- 
tion: smoking is a risk factor for hantavirus infection. Epidemiology and Infection, 138, 576-584.

Vitek C.R., Ksiazek T.G., Peters C.J., Breiman R.F. 1996. Evidence against infection with hantaviruses among forest and park workers in the southwestern United States. Clinical Infectious Diseases, 23 (2), 283-285.

Xiao S.Y., Diglisic G., Avsic-Zupanc T., Leduc J.W. 1993. Dobrava virus as a new hantavirus: evi- denced by comparative sequence analysis. Journal of Medical Virology, 39, 152-155.

Żukiewicz-Sobczak W., Zwoliński J., Chmielewska-Badora J., Galińska E.M., Cholewa G., Krasowska E., Zagórski J., Wojtyła A., Tomasiewicz K., Kłapeć T. 2014. Prevalence of antibodies against selected zoonotic agents in forestry workers from eastern and southern Poland. Annals of Agricultural and Environmental Medicine, 21 (4), 767-770. 